\title{
What I do, study, and think as an information professional
}

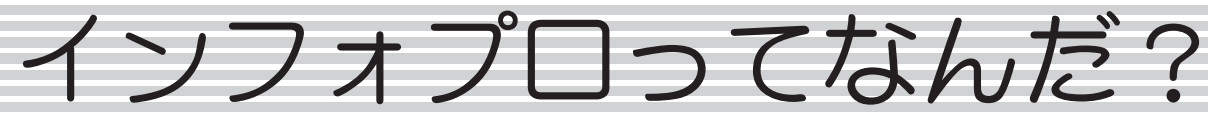

私の仕事, 学び, そして考え

\section{第 13 回剣持 和江}

\section{株式会社クラレ 新事業開発本部 知的財産部（倉敷・研究所）}

情報管理５3(1), 039-040, doi: 10.1241/johokanri.53.39 (http://dx.doi.org/10.1241/johokanri.53.39)

株式会社クラレの情報担当者になって早23年。勤 務地は美観地区・大原美術館で知られている岡山県 倉敷市。大阪まで1.5時間，東京までは4時間。都会か ら離れた地方における企業の一情報担当者としての 軌跡をご紹介しながら，若い方へのメッセージを送 りたいと思います。

入社直後は研究所の有機合成の実験室に配属，第 1子出産後生化学の実験室に。しばらくしてコン ピュータ室に異動しそこで「インフォプロ」につな がるオンライン情報検索の仕事を担当するようにな りました。配属後半年間は，私にとつての「検索の 師匠」ともいうべき直属上司の下で，ケミカルアブ ストラクツ (Chemical Abstracts: CA) のマニュアル 検索・オンライン検索の基礎をきめ細かく指導され ました。電話の受話器に似た音響力プラーを使い通 信回線速度300ボーという時代です。CA Index Guide Appendix IVを読みながら，CA命名法の講義と依頼調 査の化合物の命名実践・CAでの名寄せ，さらにはCA のページめくりの仕方・コピーの取り方に至るまで 指導されました。

配属直後，その師匠に言われたことが，「検索のプ ロフェッショナルになるんだよ，依頼されたことは 何でも対応できるように」。当時はその意味の深さも 知らず，依頼者である研究者たちの所属する研究室 の検討会での新任挨拶の時，生意気にも「検索のプ ロフェッショナルになります」と公言したのを思い 出します。
ところが半年後，師匠は大阪本社に転勤し，文献 検索の担当者は新米の私一人，さらに妊娠6か月。こ の状態でこれから迎える産前産後8週間の空白期間 をどう乗り切るか。考えた策が「研究者自らに文献 検索をしてもらう」こと，こうして20年以上前にエ ンドユーザー検索を研究所で始めることになりまし た。わからないところは師匠に電話とFAXで指導を仰 ぎながら，新米担当者が研究者にコマンド式検索の 講習会を開きました。産休明け出社後もしばらくは， 師匠に密かに相談しながら検索指導を受けることが できましたが, 間もなく師匠が退職され，とうとう「本 当に一人なんだ」と覚悟を決めました。最初の3年間 は自分の検索レベルの低さが依頼者の情報入手に影 響を及ぼしてはならないという「責任感」と「恐怖感」 にかられながら，無我夢中で過ぎました。そのうち 検索技術者認定試験（いわゆるサーチャ一試験）の 存在を知り，1990年に2級受験。

合格後，関西のインフォスペシャリスト交流会（ISForum）に入会，少しずつ周囲を見渡せるようになり 同職種他社のサーチャーとの交流に目覚めます。大 阪での「じょいんと懇話会」に参加し「パソコン通 信」・「サーチャー俱楽部」なるものを知ると，早速 職場で提案し，「社外有用情報入手ツール・社内他 地域への電子情報連絡ツール」としてパソコン通信 「Nifty-Serve」を契約。インターネットのない当時， 他事業所と電子データの送受信ができるパソコン通 信は画期的なツールでした。Nifty-Serveの提供するコ 
ミュニティサービスであるフォーラムのひとつ「サー チャ一俱楽部」では，オンライン検索技術・ノウハ ウについての熱い書き込みに驚き，本当に興奮した ものでした。自費で参加した，大阪での異業種交流 の勉強会は「検索そのもの」について議論できる場 で本当に楽しく刺激的で，この刺激が今日まで私を 検索に縛りつけているように思います。1994年度に サーチャー試験1級受験・合格。2度のサーチャー試 験の受験は検索知識・検索対象分野の幅を広げただ けでなく，他社サーチャーとの交流機会を広げるこ とができ，自分自身を大きくステップアップさせて くれるきっかけとなりました。

2000年代になり社内LAN環境が整備された一方， 2003年に図書専任者が減員され，図書・社内デー タベース管理の業務も兼務するようになり，惠まれ た「検索専任の時代」は終わりました。インター ネットの普及は著しく，電子ジャーナルが大きく動 き始めた時でした。研究者数に比較して事業所数が 多い当社にとって外国雑誌を電子ジャーナルに切り 替えることには大きなメリットがありましたが，社 内合意と全社の購読タイトルを把握することが必要 でした。そのため図書館関係の会合にも参加して， 他社の図書室・出版社の状況を把握しつつ，当社に とって納得できるコストで社内利用者に有用なコン テンツをいかに多く提供できるかを考えながら電子 ジャーナル導入を検討しました。社内合意を得なが ら計画的に電子化を進めてきた結果が現在の当社の 倉敷図書室であり，それがそのまま当社の電子ジャー ナルの環境でもあります。
私自身の業務の目指すところは，社内における学 術情報の入手環境のインフラ整備と情報利用者への 利用普及を通じて全社レベルでの研究・技術開発の 迅速化・効率化を実現することです。それがデータ ベースであっても紙の図書であっても電子コンテン ツであっても形態が異なるだけであり，これらを普 及・利用拡大していくには後進の育成が不可欠です。 2004年後進が配属され，「東京で」の情報担当者とし て順調に育ってくれています。配属の年は倉敷で長 期実習をしながら，今は（20年前の育成法では考え られなかった方法ですが)，年に数回の出張，電話・ メール・ファイル共有・パソコン会議・テレビ会議 を併用しながら，密に連絡を取り協力して業務を進 めつつ，東京という地の利を生かして自己啓発や講 習会への豊富な参加機会を享受し業務に反映してく れております。

自分自身を振り返ると，今後もまだまだ模索が続 くと思いますが「企業のインフォプロの存在意義は 何か」を常に自問しながら，検索の魅力を楽しみつつ， 仕事を進めていきたいと考えています。

\section{AINFORMATION}

【所属組織名】株式会社クラレ 新事業開発本 部 知的財産部（倉敷・研究所）

【社員数】3,053名（単体，2009年9月末現在）

【情報専任スタッフ数】4名

【サービス内容】図書・技術情報関係の情報発信・ 企画・管理・教育 